\title{
ПОСЛОВНА КОМУНИКАЦИЈА И ПОЛИТИЧАРИ - НАСТУП У МЕДИЈИМА
}

Циљ овог рада јесте да покаже како политичари иступају у медијима. Седам издања телевизијске емисије Прави угао, на Првом програму Радио-телевизије Војводине, са осам гостију - политичара чини корпус истраживања о пословној комуникацији политичара приликом наступа у медијима. Параметри који се посматрају за оцену наступа су поштовање пословног бонтона (јасан и недвосмислен говор, персирање) и аспекти невербалне комуникације: говор тела (уопште), контакт очима, израз лица, положај саговорника у простору, гестикулација и начина одевања. Анализа је показала да политичари до одређене мере контролишу своје појављивање у медијима, али да постоје специфичне ситуације у којима они несвесно реагују слањем непланиране, односно искрене поруке публици, коју би вероватно сакрили. За разлику од вербалне комуникације у којој можемо да користимо речи да сакријемо оно што стварно мислимо, сматра се да говор тела не може бити измишљен.

Кључне речи: пословна комуникација, невербална комуникација, јавни наступ, медији, телевизија, политичари.

\section{1. УВОДНЕ НАПОМЕНЕ}

Готово свако ко иступа у медијима и на тај начин се експонира данас је и те како свестан да поштовање добре праксе у пословној комуникацији значи његову/њену бољу слику у јавности, те више и боље позиционирање на политичкој сцени. Политичари су јавне личности и самим тим њихово понашање у медијима видљиво је ширем кругу људи. Начин јавног наступа кроз усклађену вербалну и невербалну комуникацију представљају изазов за сваког ко се нађе у телевизијском студију.

\footnotetext{
${ }^{1}$ pralica@ff.uns.ac.rs
} 


\section{2. ЦИЉ РАДА И ДЕФИНИСАЬЕ ПРЕДМЕТА ИСТРАЖИВАЬА}

Циљ овог рада јесте да покаже на који начин политичари у Србији иступају у медијима. Предмет истраживања јесте анализа понашања током јавног иступања осам политичара и политичарки у телевизијској емисији типа интервју на покрајинском јавном медијском сервису Радио-телевизији Војводине.

Параметри за процену наступа у медијима су: степен поштовање пословног бонтона и аспекти невербалне комуникације. Посматран је говор (стандардни/дијалекат, персирање), док је код анализе невербалне комуникације акценат био на мимици и покретима руку ${ }^{2}$, као и на начину одевања и одабиру боја.

\section{3. КОРПУС И МЕТОДОЛОГИЈА ИСТРАЖИВАЬА}

Корпус истраживања чини седам издања емисије Прави угао Телевизије Војводине. Емисија, у просеку, траје око 30 минута. Укупно је анализирано 244 минута, односно 14.640 секунди материјала.

Шест ТВ интервјуа има форму један гост - један водитељ, док је у једној емисији водитељка имала два госта. Анализа је обухватила пет мушких и два женска госта, од којих су тројица били представници опозиционих странака: Зоран Живковић, Бошко Обрадовић и Вук Јеремић, док је петоро било представника странака које чине актуелну власт: Расим Љајић, Владимир Ђукановић, Ивица Дачић, Маја Гојковић и Марија Обрадовић.

Методе које су кориштене у истраживању су: декприптивна, компаративна и метода интерпретације. Дескриптивном методом желело се описати понашање гостију за време емисије. Компаративна метода била је неопходна да упоредимо сличности и разлике у обрасцима понашања политичара, док је метода интепретације била употребљена како бисмо на основу њихових иступа и комбинације вербалне и невербалне комбинације могли да закључимо у којој мери су политичари и политичарке током јавног наступа поштовали пословни бонтон.

\footnotetext{
2 За овакав тип истраживања није било могуће узети у обзир покрете ногу будући да су ноге саговорника у потпуности заклоњене иза стола у ТВ студију.
} 


\section{4. КОНТЕКСТ ЕМИСИЈЕ}

Прави угао јесте емисија која је на Првом програму Телевизије Војводине (PTB1) сваког радног дана, сем петка, у термину од 17.20 до 17.50 часова. Емисију директно преузима и Први програм Радија Војводине (PHC1). Реч је о посебном типу емисије - лищем у лище - интервјуу. „Интервју је посебан облик разговора који се од свакодневне конверзације разликује обликом, садржајем и сложеним психолошко-комуникацијским односима који се успостављају међу саговорницима“ (Марковић 2008:157). Ауторка и водитељка емисије од самог почетка, односно маја 2015. јесте Љубица Гојгић ${ }^{3}$. Концепт емисије је такав да ауторка са једним или више гостију разговара о актуелним темама из политике, привреде, друштва и јавног живота уопште. Емисија је један од ретких примера програмског садржаја на јавном медијском сервису где гостују и представници опозиционих странака. Прави угао емитује се, по правилу, уживо из студија РTB-a у Београду. Студио има врло једноставну и сведену сценографију (слика 1$)$.

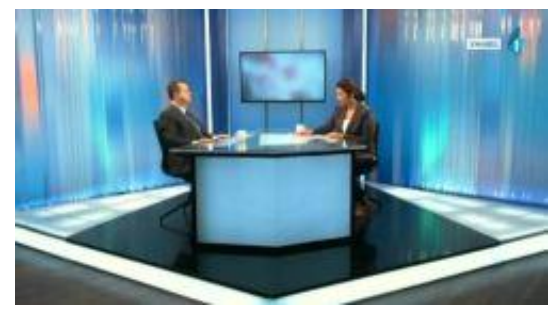

Слика 1: Студио из кога се емитује Прави угао

Симболично угласти бели сто са црним оквирима и плочом који је постављен на правоугласт црни под са белим крајевима. Сценографију чине

\footnotetext{
${ }^{3}$ Љубица Гојгић врло је угледна новинарка која је пре ауторске емисије на Телевизији Војводине 14 година радила на некадашњој Телевизији Б92. Била је специјална извештачица из Хашког трибунала и ауторка емисије Процес ТВ. Радила је и у недељнику НИН, некадашњем дневнику Демократија и некадашњем Радио Индексу (према Пејић 2017). Добитница је награде Витез професије 2018. коју на Међународни дан људских права додељују Лига експерата Лекс и Народно позориште из Београда.

${ }^{4}$ Све фотографије у раду представљају замрзнуте кадарове из емисија Прави угао чији су линкови дати на крају рада, након литературе.
} 
провидне пластичне тракасте завесе са рефлекторским плавим светлом у позадини које се пресијава у нијансе плаве боје. На средини студија налази се монитор на коме се током емисије, по потреби, приказују одређени снимци и фотографије. Са леве стране стола увек седи водитељка на црној столици са наслоном, док је десна половина резервисана за једног или два госта. Када се гледа у целини, ТВ студиом доминирају нијансе плаве боје. Та боја је добар одабир за сценографију, будући да приликом уређења простора „плаво чини да просторије делују веће, односно пространије (...) и ствара осећај бесконачности“ (Фолмар 2009:104).

Емисија Прави угао једна је од најгледанијих на PTB1 са просечним рејтингом од око 27.000 гледалаца (према Пада гледаност информативних емисија РTВ-а, 2016, пара. 19-20).

\section{5. ПОСЛОВНА КОМУНИКАЦИЈА И ПОСЛОВНИ БОНТОН}

„Вештина невербалног комуницирања једна је од најважнијих претпоставки комуникационе компетентности сваког човека понаособ“ (Радојковић, Милетић 2006: 52). Невербална комуникација има врло важну улогу и приликом јавних наступа у медијима. „За разлику од језика, невербално понашање само је делимично под нашом контролом“ (Томић 2004: 44). За квалитетну пословну комуникацију и својеврсни пословни бонтон у медијима важни су следећи фактори: употреба стандардног говора, поштовање саговорника, примерено одевање за јавне наступе, као и невербални знаци који су у корелацији са говором. Када су у питању медијски интервјуи посебно су од значаја мимика и покрети горњег дела тела, као и покрети руку.

Бројни инострани и домаћи аутори (Гофман 2000; Морис 2005; Екман 2011; Guerrero \& Hecht 2008; Lambert 2008; Hartley \& Karinch 2010; Пиз 2013; Табс 2013; Борг 2011; Радојковић и Милетић 2006; Требјешанин 2015; Рот 2004; Марковић 2008; Томић 2004; Мандић 2003; Костић 2010. и други) говоре о важности невербалне комуникације у разумевању међу људима, као и о томе да се тумачења невербалне комуникације никада не смеју применити универзално и дословно, већ да се увек мора водити рачуна о контекстуалној, културној и емоционалној условљености. 


\section{6. АНАЛИЗА И РЕЗУЛТАТИ}

\section{1. Појединачна опажања и дескрипџија}

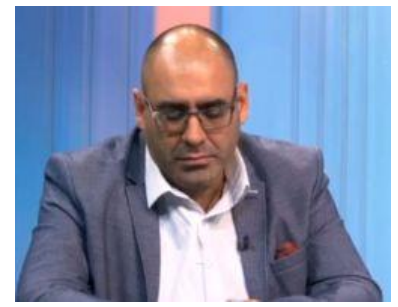

Слика 2: В. Ђукановић

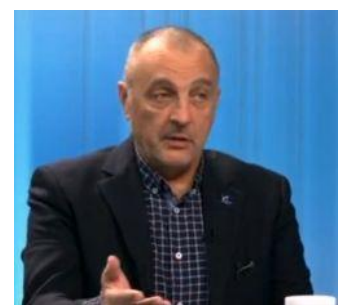

Слика 3: 3. Живковић

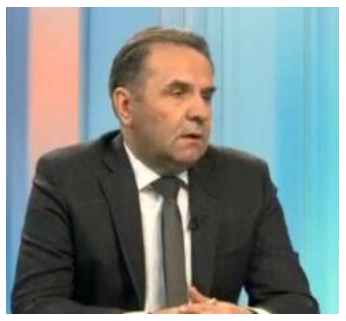

Слика 4: Р. Љајић

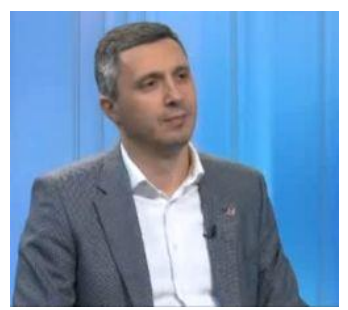

Слика 7: Б. Обрадовић

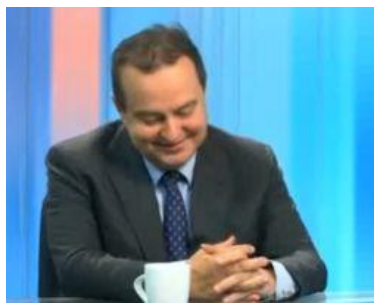

Слика 5: И. Дачић

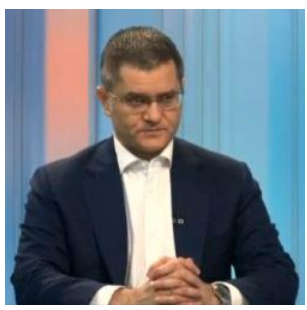

Слика 8: В. Јеремић

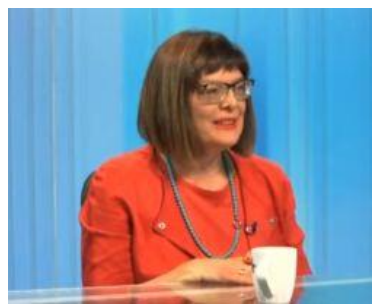

Слика 6: М. Гојковић

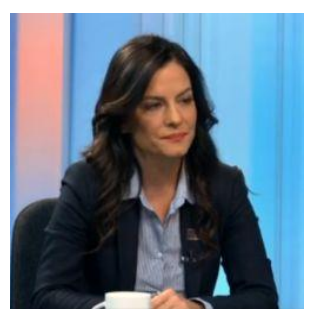

Слика 9: М. Обрадовић

\subsection{1 Владимир Ђукановић}

Владимир Ђукановић народни је посланик владајуће Српске напредне странке (СНC). У емисији је имао обучен светлоосиви сако, са црвеном марамицом у џепу и белу кошуљу, носио је наочаре. Испред себе је имао фасциклу на столу (слика 2). Говорио је умерено брзо, на моменте тихо, па гласније и брже касније. Уочено је много преклапања са водитељком и другим саговорником. Веома мало је гледао водитељку у очи. На почетку емисије имао је прекрштене руке, али када је одговарао на питања или полемисао са саговорником врло је брзо померао руке и у различитим правцима. Такође, 
нагињао се и мрштио у правцу саговорника, вербално га провоцирао. При крају емисије разговор је био на ивици да прерасте у свађу.

\subsection{2 Зоран Живковић}

Зоран Живковић народни је посланик и председник опозиционе Нове странке. У емисији је имао обучен црни сако са тамноплавом кошуљом на беле коцкице. Испред себе на столу имао је папир и оловку, као и наочаре које је ставио тек при крају емисије када је читао (слика 3 ).

Деловао је узнемирено и нервозно готово цео ток емисије. Није се смејао. Користио је непримерене изразе, вербално нападао саговорника Владимира Ђукановића, ретко га је гледао у очи. На почетку емисије прекрштене, руке је врло брзо покретао у вазуху. Провоцирао је саговорника, а водитељка га је једанпут јасно опоменула.

\subsection{3 Расим Љајић}

Расим Љајић је министар трговине и председник Социјалдемократске странке која је у коалицији са СНС-ом. У емисији је носио тамносиви сако, белу кошуљу и светлосиву кравату. Говорио је сталожено, умерено и без нервозе. Није имао папир на столу (слика 4). Љајић се осећао сигурно у емисији, углавном је контролисао покрете руку које су биле прекрштене испред, повремено скупљајући прсте и отварајући руке према водитељки. Читаву емисију деловао је отворено за разговор.

\subsection{4 Ивица Дачић}

Ивица Дачић је потпредседник Владе и министар спољних послова, као и председник Социјалистике партије Србије која је у коалицији са СHCом. Носио је тамносиви сако, светлоплаву кошуљу са тамноплавом краватом на светлоплаве детаље. Испред себе није имао папире (слика 5). На почетку емисије држао је прекрштене руке које је касније покретао скупљајући прсте, или правећи песнице. У односу на све остале, имао је највише гестова самодидиривања (чешкање по лицу, коси, намештање ревера на сакоу), често осмехивање, као и грижење усне и померање у столици. 


\subsection{5 Маја Гојковић}

Маја Гојковић председница је Народне скупштине и чланица владајуће СНC. У емисији је носила црвени сако са плавим ланчићем од перли. Кармин је био у боји сакоа. Носила је наочаре. Испред себе није имала папир. На почетку емисије била је само шакама наслоњена на сто, смешкала се док говори (слика 6). Руке су углавном биле наслоњене на сто, са повременим отварањима. У другом делу емисије имала је неколико преклапања са водитељком, гестова самододиривања (косе, ланчића). При крају емисије обе руке стискала је у песнице. Користила је метафоричне изразе.

\subsection{6 Бошко Обрадовић}

Бошко Обрадовић је народни посланик и председник опозиционе странке Двери. Носио је тамносиви сако и белу кошуљу. Од почетка емисије клатио се у столици. Углавном је брзо говорио. Није имао папир испред себе (слика 7). Обрадовић је веома много гестикулирао рукама (сечење кроз вазух, показивање ка себи, високо дизање у ваздух једне руке). Често се осмехивао и подизао обрве. Одржавао је контакт очима са водитељком доследно.

\subsection{7 Вук Јеремић}

Вук Јеремић је председник опозиционе Народне странке. На себи је носио тамноплави сако и белу кошуљу. Имао је наочаре, а испред себе није имао папир. Често је држао прекрштене руке на столу (слика 8). Говорио је сталожено и одмерено. Повремено је подизао обрве, самоуверено показивао на себе, слегао раменима. Дизао је руке у ваздух док је објашњавао одређене појмове, махао рукама лево-десно, повремено се осмехивао, а при крају емисије клатио се у столици.

\subsection{8 Марија Обрадовић}

Марија Обрадовић је народна посланица и потпредседница владајуће CHC. На себи је имала тамноплави сако, белу кошуљу на светлоплве пруге, опуштену уредну косу и дискретно је била нашминкана. Читаву емисију била је сталожена, самоувереног става, стиснутих усана (слика 9). Говорила је умереним темпом. Готово кроз целу емисију имала је високо подигнуту главу, повремено отварајући дланове и пребацујући једну преко друге шаке. 
Читавим током емисије гестикулирала је рукама. Неколико пута је намештала фризуру, дизала обрве и мрдала се у столици.

\section{2. Компаративна анализа}

\begin{tabular}{|c|c|c|c|c|c|c|c|}
\hline $\begin{array}{l}\text { Саговорник/ } \\
\text { саговорница }\end{array}$ & боје одеће & $\begin{array}{c}\text { изражајна } \\
\text { мимика }\end{array}$ & $\begin{array}{c}\text { покрети } \\
\text { руку }\end{array}$ & $\begin{array}{c}\text { гестови } \\
\text { самододиривања }\end{array}$ & $\begin{array}{l}\text { темпо и } \\
\text { јачина } \\
\text { говора }\end{array}$ & $\begin{array}{c}\text { употреба } \\
\text { жаргона } \\
\text { или } \\
\text { метафора }\end{array}$ & $\begin{array}{c}\text { помоћна } \\
\text { средства } \\
\text { (папир, } \\
\text { оловка) }\end{array}$ \\
\hline $\begin{array}{l}\text { Владимир } \\
\text { Ђукановић }\end{array}$ & $\begin{array}{c}\text { светлосива } \\
\text { бела } \\
\text { црвена } \\
\end{array}$ & очигледна & чести & да & $\begin{array}{c}\text { умерен, } \\
\text { повремено } \\
\text { брз }\end{array}$ & да & да \\
\hline $\begin{array}{l}\text { Зоран } \\
\text { Живковић }\end{array}$ & $\begin{array}{c}\text { црна } \\
\text { тамноплава } \\
\text { бела } \\
\end{array}$ & очигледна & чести & да & $\begin{array}{c}\text { умерен, } \\
\text { повремено } \\
\text { брз }\end{array}$ & да & да \\
\hline $\begin{array}{l}\text { Расим } \\
\text { Љајић }\end{array}$ & $\begin{array}{c}\text { тамносива } \\
\text { бела } \\
\text { светлосива }\end{array}$ & сведена & умерени & не & умерен & не & не \\
\hline $\begin{array}{l}\text { Ивица } \\
\text { Дачић }\end{array}$ & $\begin{array}{c}\text { тамносива } \\
\text { светлоплава } \\
\text { тамноплава }\end{array}$ & очигледна & чести & да & $\begin{array}{c}\text { умерен, } \\
\text { повремено } \\
\text { брз }\end{array}$ & да & не \\
\hline $\begin{array}{l}\text { Маја } \\
\text { Гојковић }\end{array}$ & $\begin{array}{c}\text { црвена } \\
\text { светлоплава }\end{array}$ & сведена & умерени & да & умерен & да & He \\
\hline $\begin{array}{l}\text { Бошко } \\
\text { Обрадовић }\end{array}$ & $\begin{array}{c}\text { тамносива } \\
\text { бела }\end{array}$ & очигледна & чести & не & $\begin{array}{c}\text { брз, } \\
\text { повремено } \\
\text { умерен } \\
\end{array}$ & & не \\
\hline $\begin{array}{l}\text { Вук } \\
\text { Јеремић }\end{array}$ & $\begin{array}{c}\text { тамноплава } \\
\text { бела } \\
\end{array}$ & очигледна & чести & не & умерен & не & не \\
\hline $\begin{array}{l}\text { Марија } \\
\text { Обрадовић }\end{array}$ & $\begin{array}{c}\text { тамноплава } \\
\text { бела } \\
\text { светлоплава }\end{array}$ & сведена & умерени & да & умерен & He & не \\
\hline
\end{tabular}

Табела 1. Компаративна анализа - преглед

\subsection{1 Употреба (не)стандардног језика}

Анализа говора свих осам саговорника показала је да политичари у јавним наступима углавном користе стандардни језик, персирање и изразе који су недвосмислени и општепознати широј публици. „Говорна култура не представља само тежњу ка однегованом језику, већ употребу и способност говорника да се прилагоди свакој ситуацији и да увек остане на нивоу и висини доброг казивања“ (Марковић 2008: 46). Ипак, код четворо саговорника уочено је повремено одступање од формалног говора и употреба метафора, кованица или реченичких конструкција које нису део стандардне, јавне комуникације. 
Ивица Дачић, на пример, када говори о утицају турског председника на ситуацију у Босни и Херцеговини повиси тон и дословно каже:

- $\quad$ „Док није Ердоган ускочио, они ${ }^{5}$ нису могли да се договоре којом трасом ће да крене аутопут.“

Или када говори о посвећености Србије да постане чланица Еворпске уније каже:

- „Ја нисам баш еурофанатик.“

и након тога се угризе за доњу усну, што је у невербалној комункацији знак нервозе односно, чини се, као да се каје што је то изговорио, као да му је та мисао излетела.

Маја Гојковић, приликом разговора о томе зашто власт не мења старе

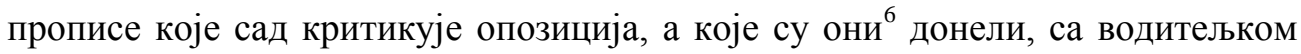
разговара на неуобичајен начин у јавном дискурсу, алудирајући на то да су важећи прописи добри и да их неће мењати:

- Љубица Гојгић: „У тим, разгаженим ципелама се, очигледно, боље oceћaтe?"“

- Маја Гојковић: „Па увек се у старим ципелама боље осећате него у новим. Мало стежу, али није никакав проблем, нека дођу“ (смех).

- Љубица Гојгић: „То Вам није чак ни женски аргумент“ (смех).

- Маја Гојковић: „Је л' није женски? Ја мислим да јесте. На венчању увек носим старе ципеле, боље се осећам“.

Ипак, највише одступања од правила добре пословне комуникације у медијима имали су Зоран Живковић и Владимир Ђукановић који су заједно гостовали у емисији. Саговорници се међусобно нису поштовали, а на моменте разговор је прерастао у свађу. Ђукановић има врло негативно мишљење према представници Европског парламента Тањи Фајон која је посредовала на састанку у вези са дијалогом власти и опозиције у Србији.

\footnotetext{
${ }^{5}$ Мисли се на Босну и Херцеговину (прим. аут.)

${ }^{6}$ Садашња опозиција док је била на власти (прим. аут.)
} 
Када говори о њој, не користи персирање и претвара се као да јој се лично обраћа, као да је она са њим у студију:

- „Ти си дошла на званични састанак; Шта ти имаш тајно да преговараш?“ (слика 10).

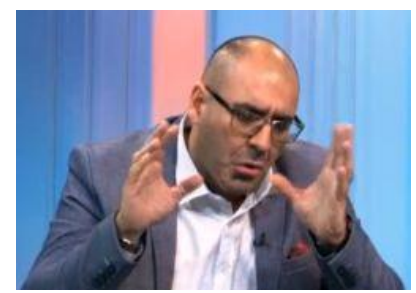

Слика 10: Покрети лица и тела кад критикује представницу Европског парламента

Ове констатације уз намрштене обрве, погнуту главу и махања рукама упућују на то да особа заузима негативан, агресиван став - погнута глава (према Пиз 2013:247), док „диригентски знаци дају такт и ритам изговореним мислима“ (Морис 2007: 71), то јест појачавају изговорено. Ђукановић такође полемише са саговорником Живковићем уз следећу опаску:

- „Ви новинаре називате курвама. Избацујете их са конференције“.

Кулминација непримерене јавне комуникације догађа се у самом финишу емисије када Зоран Живковић са папира чита дијагнозу у којој оптужује лидера CHC-а да је болестан:

- „Параноидна шизофренија од које болује доказано њихов председник.“,

показујући хемијском на Ђукановића. У том тренутку реагује и водитељка која подиже леву руку ка Живковићу као знак cmon у намери да га заустави у даљем говору (слика 11):

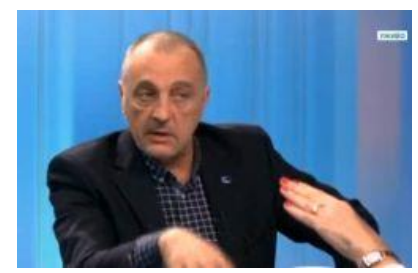

Слика 11: Водитељка прекида Живковића 
Живковић, видно нервозан и изнервиран током емисије, говори и следеће:

- „То је атмосфера свињарије коју су научили од Вучића који упада у реч, који се понаша ненормално.“

- ШШо пре емисије не узмете терапију? (провоцира саговорника)

- То је свињарија на нивоу једне друге животиње“;

- „То је дрипачки“;

- „То је дивљање““

Потврђује више пута климањем главом опаску Ђукановића да је за TB Пинк он (Живковић) рекао да је ђубре. Бори се за реч против саговорника којег у једном тренутку и додирује десном руком да га заустави, што представља једини физички контакт између саговорника у анализираном корпусу (слика 13):

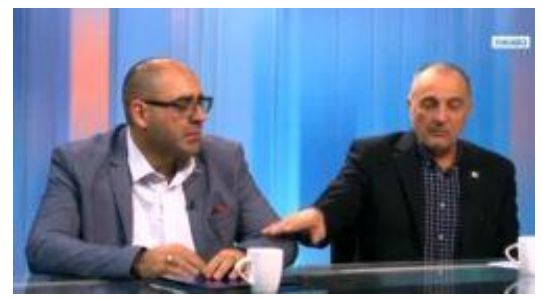

Слика 12: Живковић ућуткује Ђукановића

\subsection{2 Пословно одевање и боје}

У пословној комуникацији, међутим, врло је важно како ће учесници бити обучени, нарочито ако је у питању гостовање у медијима. „Одећа може указивати на доживљај личности дате особе, на социјални и професионални статус, као и на улогу коју нека особа управо одиграва“ (Томић 2004:46). У овом истраживању, претпоставка је била да сви актери имају приближно исти професионални статус - посматрамо их као јавне личности. У складу са тиме одећа, такође скреће пажњу на особу која се појављује у јавности. „Погрешна је одлука да се слепо спроводе модни трендови“ (Марковић 2008:191). У анализирамим примерима то није био случај.

Седам од осам политичара на себи је имало сако и кошуљу испод, једино је Маја Гојковић имала црвену блузу, без сакоа. Трећина мушких саговорника носила је кравату (Расим Љајић и Ивица Дачић). Други модни детаљ, сем кравате, имао је једино Владимир Ђукановић - марамицу у џепу 
сакоа, као и Маја Гојковић ланчић од перли. Занимљива је чињеница да су Љајић и Дачић једини од саговорника представници извршне власти министри, па су у складу са тиме и били у потпуности формално, пословно одевени. Сматра се да се марамица у сакоу носи, по правилу, у вечерњим терминима $^{7}$, као и уз слагање у тону са краватом и лептир-машном, што у примеру Ђукановића није био случај, будући да није имао ни кравату, ни лептир-машну.

Сматра се да су „боје феномен чије се значење мења зависно од друштвеног контекста, али чија је важност у комуникацији у људском друштву константна“ (Мирков 2012:126). Боје које су доминирале у избору саговорника биле су: плава (седам примера са нијансама светло или тамно), бела (шест примера) и сива (пет примера са нијансама светло или тамно) (графикон 1):

У два случаја избор је црвена и једанпут црна боја. Анализа је показала да је већина саговорника добро уклопила и искористила боје када је у питању представљање у јавности. За плаву боју сматра се да је „боја конвенције“, да изражава „промишљеност и суздржаност“ (према Фолмар 2009: 103-104). Бела асоцира на „моћ, чисто, добро и здраво“ (према Фолмар 2009: 323). За сиву комбинацију сматра се да одражава просечност, да може „увек да се обуче“ и да представља „суздржану елеганцију“ (према Фолмар 2009: 356). За црвену боју (два примера) се сматра да „греје“, да је „доминатна и динамична“ боја која скреће пажњу“ (према Фолмар: 2009: 144; 150). Значење црне боје (један примера) доводи се у везу са симболиком моћи, службе и бизниса, „ствара дистанцу и делује ауторитативно“ (према Фолмар 2009: 313-314).

На основу анализе можемо закључити да се већина саговорника придржавала правила употребе пословне одеће и одабира боја, са изузетком Маје Гојковић која је бојом своје блузе скретала пажњу на себе више него што је у медијском наступу оваквог типа емисије потребно. Теоретичари, попут Гербрана и Шевалијеа, сматрају како „говорници, углавном бирају одећу по осећају“ чиме откривају да ли су искрени када говоре на одређену тему (према Гербран, Шевалије 2004:50).

\footnotetext{
${ }^{7}$ Емисија је на програм у поподневним сатима, а вечерњи сати рачунају се после 18 часова.
} 


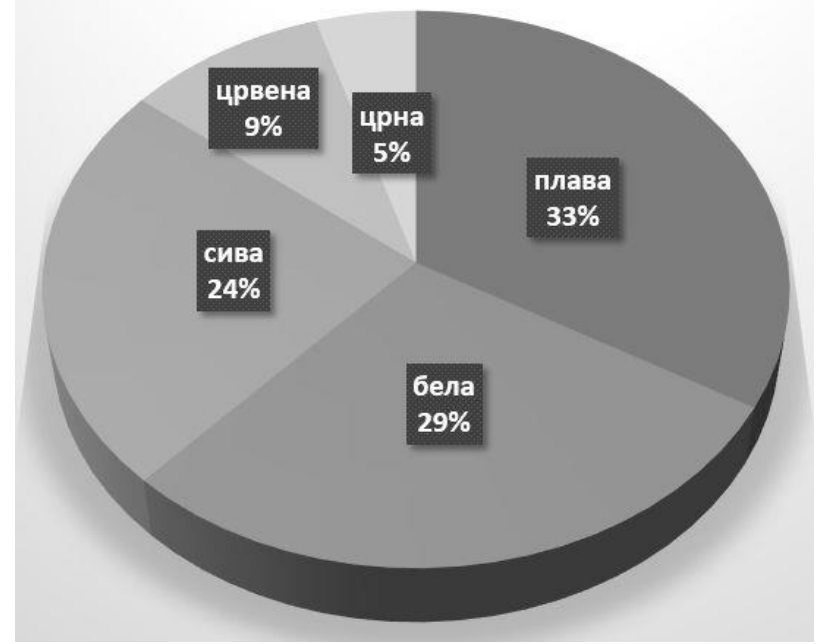

Графикон 1: Избор боје одеће

\subsection{3. Небербална комуникација у интервјуу}

Многи лаици невербалну комуникација погрешно сматрају секундарним видом комуникације која само доприноси примарној, вербалној комуникацију. Њено посматрање и правилно тумачење врло је важно за одређивање и разумевање великог броја ситуација и образаца понашања говорника, нарочито приликом јавних наступа. „Невербални комуникациони знакови“ могу да истакну „оно што је речено“, али и да промене „смисао ономе што је вербално саопштено“ (према Рот 2004: 97). За разлику од вербалне комуникацијеу којој можемо да користимо речи да сакријемо оно што стварно мислимо, сматра се да говор тела не може бити измишљен.

\subsubsection{1 Диригентски знащи}

Дезмонд Морис утврдио је да овакви знаци „дају такт и ритам изговореним речима“. Толико су се интегрисали у наш говор да „понекад гестикулишемо чак и ако са неким разговарамо телефоном“ и не видимо се (према Морис 2005: 71). Анализа је показала да диригентске знаке политичари веома користе у јавним наступима на медијима (слике 13-18). 


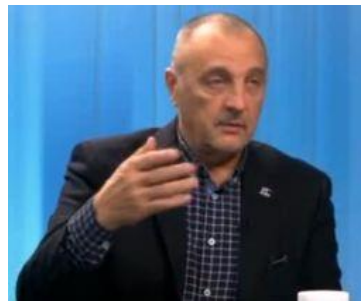

Слика 13.

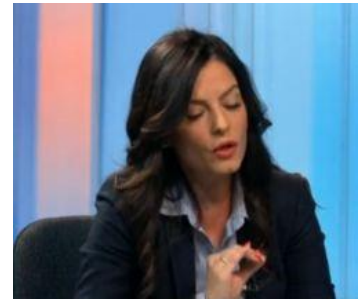

Слика 16.

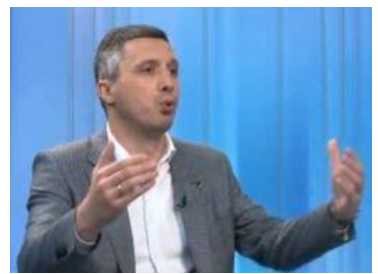

Слика 14.

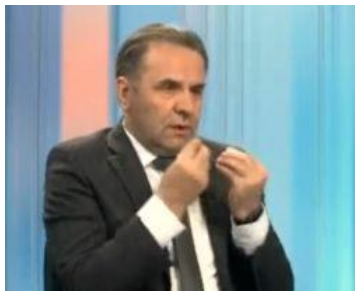

Слика 17.

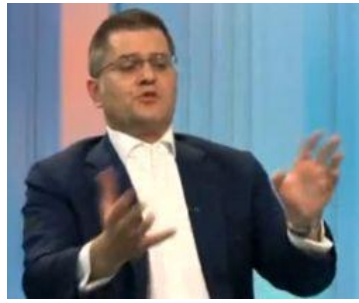

Слика 15.

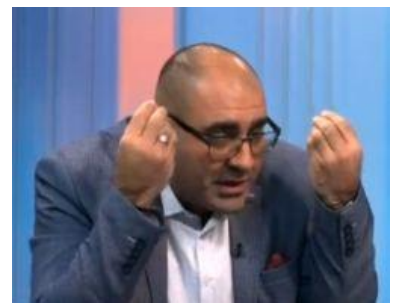

Слика 18.

Невербална рекација Живковића уследила када је критиковао владајућу коалицију (слика 13). Бошко Обрадовић користио је диригентске знаке да опише најаву великог протеста опозиције (слика 14). Јеремић је вртео рукама у ваздуху када је желео да објасни шта значи радикализација протеста опозиције (слика 15). Марија Обрадовић подигла је десну руку и скупила прсте када је желела да подвуче да осуде сексуалног узнемиравања не смеју да се доводе само у везу са актуелном влашћу (слика 16). Љајић је уз помоћ дизања руку и скупљања прстију према себи покушао да подвуче разлику између (у делу јавности критикованог) споразума Србије са Евроазијском унијом и Трговинског споразума са Европском унијом (слика 17). Ђукановић је од диригентских знакова користио скупљене прсте (слика 18) у комбинацији са спуштањем главе када је видно изнервиран викао у правцу водитељке:

- „Зовите опозицију што чешће! Ја не знам шта више да урадимо?! Да се исечемо? Да се спалимо? Шта хоћете?!“

Може се уочити извесна сличност у томе кад политичари, на неки начин, желе да скрену пажњу на то да су тобоже немоћни да нешто ураде јер су више пута поновили речено (примери Љајића и Ђукановића). 


\subsubsection{2 Фащијална експресија}

Фацијална експресија или мимика има такође врло важну улогу у дешифровању одређених порука коју нам шаљу политичари. Комбинација осмеха, па чак и различитих врста осмеха са померањем руку шаље нам поруку о томе да ли је изговорена реченица искрена или се њоме нешто желело прикрити (слике 19-22). Лажан или исконструисан осмех често је несиметричан и „изгледа израженије на једној страни лица него на другој, будући да се обе стране мозга труде да постигну да делује искрено“ (Пиз 2013: 86).

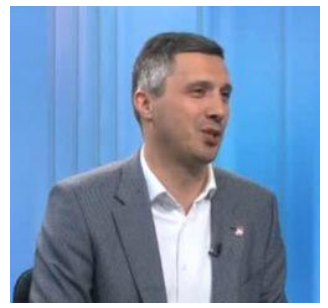

Слика 19.

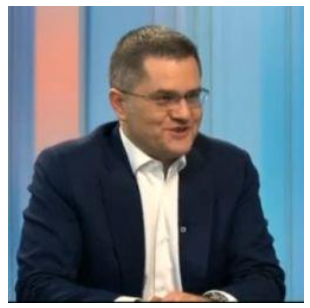

Слика 20.

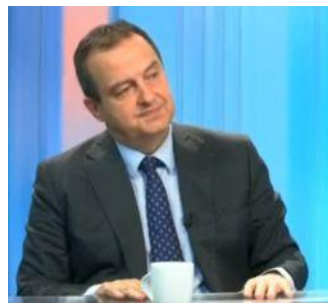

Слика 21.

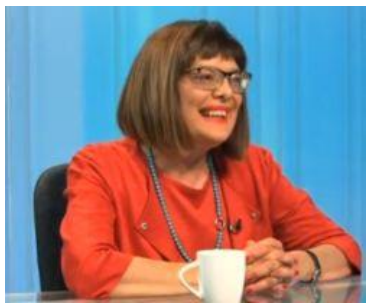

Слика 22.

Бошко Обрадовић (слика 19) киселим осмехом прикрива непријатност када говори о сопственој шали да би хапсио новинара Бошка Јакића због става о Косову. Јеремић конструисаним, неискреним осмехом (слика 20) прикрива непријатност у којој се осећа због правдања зашто и он није ушао у зграду PTC-а током протеста опозиције. Дачић изводи сведен осмех, са угрзиом доње усне (слика 21), у комбинацији са искривљеном главом у тренутку када изговара да он није еурофанатик, тиме несвесно шаљући аудиторијуму поруку да му није пријатно што је то јавно рекао, будући да је званична политика Владе проевропска. Искривљена глава представља подражавање инфантилне радње када смо били деца и симболизује невиност, а Дачић тиме као да жели да поручи аудиторијуму да му не замери на искрености. Маја Гојковић се неприродно смеши када са водитељком разговара о могућностима промене прописа у Народној скупштини. Њен говор паралелно прати осмех са делимично спуштеном вилицом уз прекрштене руке. Комбинација ових невербалних знакова указује да се особа ипак не осећа пријатно, али да жели то да прикрије. Ово је увежбани тип осмеха „код којег се доња вилица једноставно спушта, да би одавала утисак да се особа смеје или је весела“ (Пиз 2013: 89-90). Такође, укрштени прсти тумаче се нервозом или изражавају одбрамбени став (према Борг 2011: 121-122). 


\subsubsection{3 Знаии доминащије}

Знаци доминације и моћи могу се препознати на основу положаја тела, држања главе и руку. Сигурна и ауторитативна особа за столом седи усправно, подигнуте главе или главе благо забачене назад, при чему делимично истура браду у предњи план. Руке су мирно на столу (или наслонима столице, ако постоје) окренуте ка ниже, ка површини стола. Такав положај руку „исказује власт и ауторитет“, док у комбинацији са песницом „са испруженим кажипрстом“ указује на моћ и „симболичну батину“ (према Пиз 2013: 50-53) (слике 23-25):

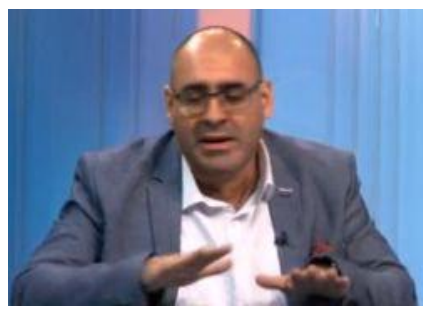

Слика 23.

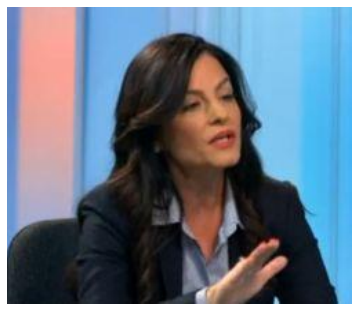

Слика 24.

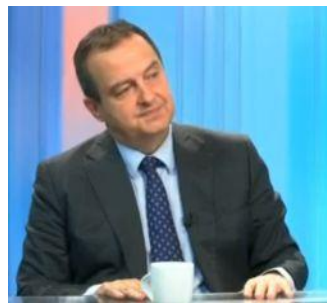

Слика 25.

Све три особе, по положају руку, показују да се осећају ауторитарно, стабилно и моћно. Ипак, постоје разлике. Ђукановић и Обрадовићева знаке доминације показују у тренуцима када се обраћају водитељки. Ђукановић у том тренутку говори како новинари у емисије не треба да позивају чланове CHC-a, као да им то није потребно. Ђукановић према Љубици Гојгић:

- „Молим Вас да СНС нема ни један једини секунд током предизбоне кампање у медијима.“

Марија Обрадовић (слика 24) водитељки ставља до знања да није завршила мисао и да је не прекида. Са друге стране, Дачић дланове држи на столу у тренутку када му је било непријатно што је нешто изговорио, а није требало. У овој ситуацији отворени дланови ка столу могу се тумачити као гестови самоутехе, односно самопоуздања јер је он ипак део власти, а не представник опозиције. 


\subsubsection{4 Знаци несигурности - невербално иурење}

Знаци који тумачу невербалне комуникације указују на нервозу и нелагоду очитују се у несвесним покретима које би саговорници најрадије прикрили, а који се дешавају ван воље. То су знаци самододиривања врата, образа, носа, уређивање одеће без разлога, додиривање накита, намештање наочара, поправљање кравате и слично. Тако преклопљене руке сугеришу на „сузбијање негативног понашања које жели да се прикаже“, док укрштени прсти указују „на нервозу или одбрамбени став“ (према Борг 2011: 118-122) (слике 26 и 27).

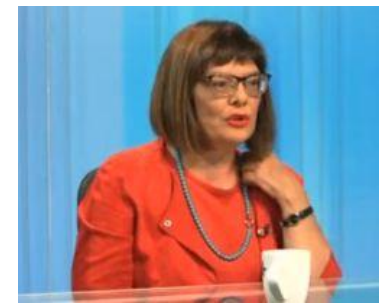

Слика 26.

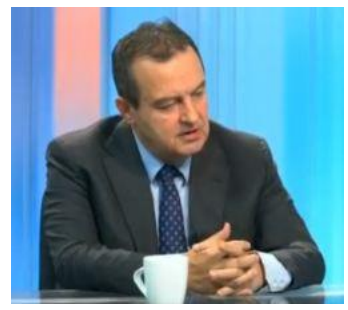

Слика 27.

Маја Гојковић чешка се по врату и додирује ланчић (слика 26) у моменту када говори о опозицији и о томе колико опозиционих посланика се вратило у скупштинске клупе. Дачић преплиће и стиска прсте (слика 27) одговарајући на питање водитељке да појасни шта је то еурофанатик. Дачић је имао више ситуација кад се додиривао по лицу или поправљао ревер на сакоу и то у моментима када је говорио о несагласју унутар своје странке, као и кад је напоменуо да he ce француски председник Емануел Макрон „заложити и за српске интересе“, што се може протимачити као нелагодност.

На основу наведених примера може се потврдити став да „неки људи својим изгледом, облачењем и мимиком веома добро представљају себе онако како то желе, док су други упркос великом труду у томе неуспешни“ (Требјешанин, Жикић 2015: 40).

\section{7. ЗАКЉУЧНЕ НАПОМЕНЕ}

Анализа наступа осам политичара током гостовања у телевизијској емисији показала је да они у већој мери контролишу своје појављивање у медијима, али да постоје специфичне ситуације у којима несвесно реагују и 
невербалним говором шаљу непланиране поруке публици, које би иначе, вероватно, сакрили.

Већина посматраних политичара користила је стандардни језик и поштовала правила пословне комуникације у јавном телевизијском наступу. Изузетак су Владимир Ђукановић и Зоран Живковић чије је заједничко иступање у једној емисији било на ивици свађе, уз употребу ироније, провоцирања и погрдних израза, што никако не доприноси дијалогу и култури.

Сви анализирани политичи носили су гардеробу која је примерена пословној комуникацији, односно појављивању у телевизијском програму, у озбиљној емисији као што је Прави угао. Када је одабир детаља у питању, изутетак је Владимир Ђукановић који у реверу носи марамицу, иако је такав модни детаљ, по правилу, резервисан само ако особа има кравату или лептирмашну. Нијансиране сива и плава боја биле су најчешћи избор већине политичара, са изузетком Маје Гојковић која је носила црвену блузу и тиме више него што је потребно скретала пажњу на своју гардеробу.

Политичари су, са изузетком Расима Љајића који мимиком углавном није показивао емоције, фацијалну експресију, изрежирани смех, мимику употребљавали у ситуацијама када су говорили о, за њих, непријатним темама, што се може тумачити жељом да смехом ублаже такве стресне тренутке. Знаци доминације уочени су код троје саговорина и то код свих троје који су припадници владајуће партије или коалиције. Сигнали неугодности могли су се уочити у тренуцима кад су актери, без потребе, поправљали своју одећу (ревере, крагне), додиривали се по лицу и врату, намештали наочаре и фризуру када за то објективно није било поребе, клатили се у столици и преплетали прсте.

Анализа је показала да су политичари, по правилу, припремљени за наступ у медијима и да поштују правила пословне комуникације. Одсуство добре праксе забележено је једино у емисији у којој су била два госта супротстављених ставова. У сваком тренутку јавне личности треба да имају на уму да је дијалог начин размене мишљења, а да су у телевизијском дијалогу изложени погледима аудиторијума. „Резултат креативног приступа говорном чину јесте слобода говора, уважавање туђег мишљења и поштовање правила говора у јавности“ (Марковић 2008:30), а то је нешто у чему део овдашњих политичара још треба да се усавршава. 
Dejan Pralica

BUSINESS COMMUNICATION AND POLITICS - APPEARING IN THE MEDIA

\section{Summary}

The aim of this paper is to show how Serbian politicians behave in the media. Eight editions of the Pravi ugao interview broadcast on Channel 1 of Radio-Television of Vojvodina make the corpus for this material. The author had nine guests overall, or more precisely in seven interviews there was one guest and in one interview there were two guests. The parameters considered for evaluating public appearances are respect for business etiquette (clear and unambiguous speech, persecution) and aspects of non-verbal communication that are used to evaluate public appearances of politicians such as: body language (in general), eye contact, facial expressions, the position of the interlocutor in space, gestures and their clothes. The analysis shows that politicians control their appearance in the media to a certain extent, but that there are specific situations in which they unwittingly respond by sending an unplanned or honest message to the audience that they might otherwise hide. Unlike verbal communication, in which we can use words to hide what we really mean, body language is considered to be spontaneous and genuine.

Key words: business communication, nonverbal communication, media, television, politicians.

\section{ЛИТЕРАТУРА}

Борг, Џејмс (2011). Говор тела: како да знамо шта је заиста изговорено. Зрењанин: Сезам бук.

Гербран, Ален и Шевалије, Жан (2004). Речник симбола. Нови Сад: Стилос.

Гофман, Ервинг (2001). Како се представљамо у свакодневном животу. Београд: Геопоетика.

Guerrero, Laura K. \& Hecht, Michael L. (ed.) (2008). The Nonverbal Communication Reader, $3^{\text {rd }}$ edition. Long Grove: Waveland Press.

Екман, Пол (2011). Разоткривене емоиије. Београд: Завод за уџбенике.

Lambert, David. (2008). Body Language 101: The Ultimate Guide to Knowing When People Are Lying, How They Are Feeling, What They Are Thinking, and More. New York: Skyhorse Publishing.

Костић, Александра. (2010). Говор лица: значења фаџијалних понашања. Ниш: Филозофски факултет.

Мандић, Тијана. (2003). Комуникологија: психологија комуникащије. Београд: Клио.

Марковић, Марина. (2008). Пословна комуникаџија са пословним бонтоном. Београд: Клио. 
Мирков, Лидија (2012). Невербална комуникација бојама у јавном наступу. ЦМ - часопис за управљање комуницирањем, бр. 25, год. 7, стр. 125142.

Морис, Дезмонд. (2005). Откривағе човека: водич кроз говор тела. Ниш: Зограф.

Пада гледаност информативних емисија РТВ (29.12.2016). У: портал Аутономија. Преузето 29.11.2019. ca https://www.autonomija.info/padagledanost-informativnih-emisija-rtv.html

Пејић, Драган (2017). Љубица Гојгић: одувек хоћу да лаву измерим реп. Преузето 29.11.2019. ca https://www.blic.rs/vesti/drustvo/ljubica-gojgicoduvek-hocu-da-izmerim-lavu-rep/1r7h4lj

Пиз, Алан. и Пиз, Барбара. (2013). Дефинитивни водич крзо говор тела. Београд: Вулкан.

Радојковић, Мирољуб и Милетић, Мирко (2006). Комуницирање, медији и друштво. Нови Сад: Стилос.

Рот, Никола (2011). Знакови и значења - вербална и невербална комуникаџија. Београд: Плато.

Табс, Стујарт (2013). Комуникащија: принциии и контексти. Београд: Клио.

Томић, 3. (2004). Комуникација и јавност. Београд: Чигоја штампа.

Требјешанин, Жарко и Жикић, Бојан (2015). Невербална комуникаиија антрополошко-психолошки приступ. Београд: Завод за уџбенике.

Фолмар, Клаусбенд (2008). Велика къига о бојама. Београд: Лагуна.

Hartley, Gregory \& Karinch, Maryann. (2010). The Body of Language Handbook: How to Read Everyone's Hidden Though and Intentions. Pompton Plains, New Jersey: Career Press.

Емисије:

http://media.rtv.rs/sr_lat/pravi-ugao/51615 (18.11.2019. гости Владимир Ђукановић (СНC) и Зоран Живковић председник Нове странке) 34 мин.

http://media.rtv.rs/sr_lat/pravi-ugao/51023 (28.10.2019. гост министар трговине Расим Љајић (СДП)) 32 мин.

http://media.rtv.rs/sr_lat/pravi-ugao/50486 (09.10.2019. гост министар спољњих послова Ивица Дачић (СПС)) 33 мин.

http://media.rtv.rs/sr_lat/pravi-ugao/48047 (18.06.2019. гошћа председница Народне скупштине Маја Гојковић (СНС)) 36 мин.

http://media.rtv.rs/sr_lat/pravi-ugao/46075 (11.04.2019. гост председник покрета Двери Бошко Обрадовић) 36 мин. 
http://media.rtv.rs/sr_lat/pravi-ugao/45372 (18.03.2019). гост председник Народне странке Вук Јеремић) 35 мин.

http://media.rtv.rs/sr_lat/pravi-ugao/45029 (07.03.2019). гошћа потпредседница CHC-а Марија Обрадовић) 38 мин. 